\title{
Elysium as a Social Allegory: At the nexus of Dystopia, Cyberpunk, and Plutocracy
}

Emre Ulusoy

Youngstown State University

Follow this and additional works at: https://digitalcommons.uri.edu/mgdr

Part of the Anthropology Commons, Critical and Cultural Studies Commons, Economics Commons, Film and Media Studies Commons, Marketing Commons, Other Business Commons, and the Sociology Commons

\section{Recommended Citation}

Ulusoy, Emre (2020) "Elysium as a Social Allegory: At the nexus of Dystopia, Cyberpunk, and Plutocracy," Markets, Globalization \& Development Review: Vol. 5: No. 3, Article 5.

DOI: $10.23860 / M G D R-2020-05-03-05$

Available at: https://digitalcommons.uri.edu/mgdr/vol5/iss3/5

This Media Review is brought to you for free and open access by DigitalCommons@URI. It has been accepted for inclusion in Markets, Globalization \& Development Review by an authorized editor of DigitalCommons@URI. For more information, please contact digitalcommons-group@uri.edu. 


\section{Markets, Globalization \& Development Review}
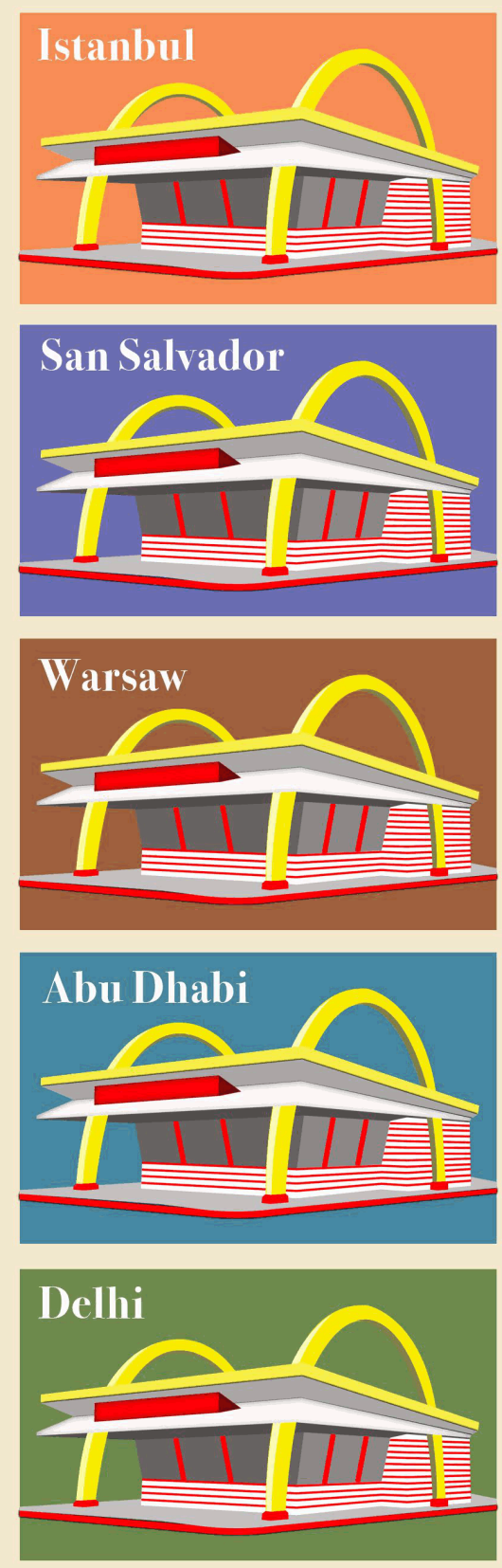
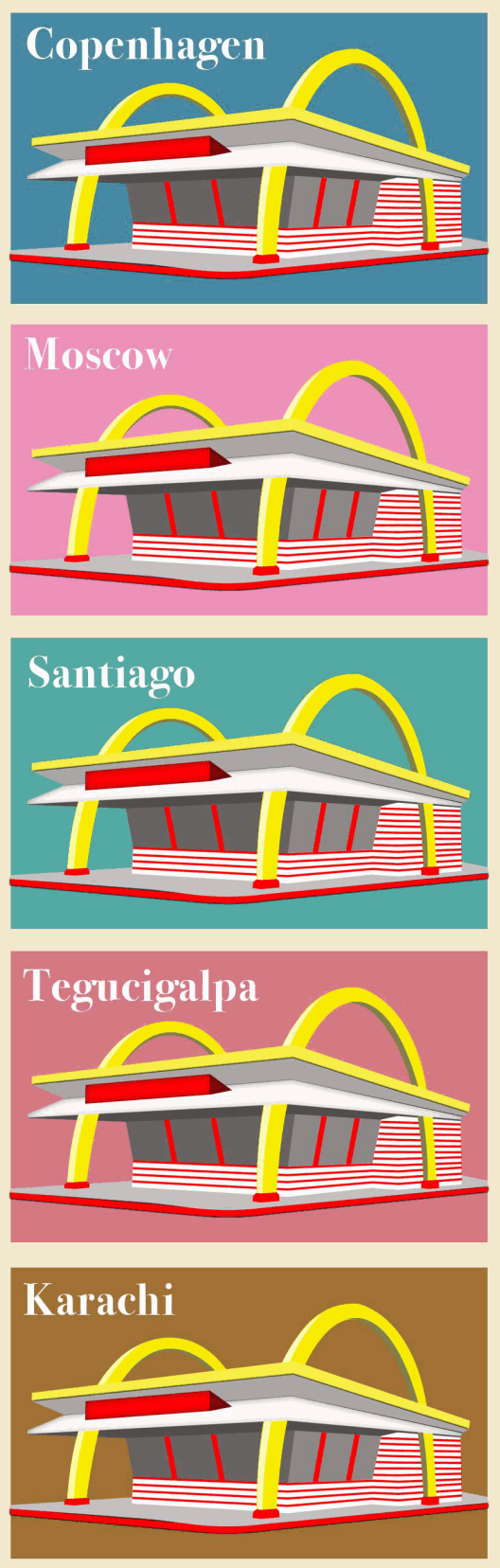
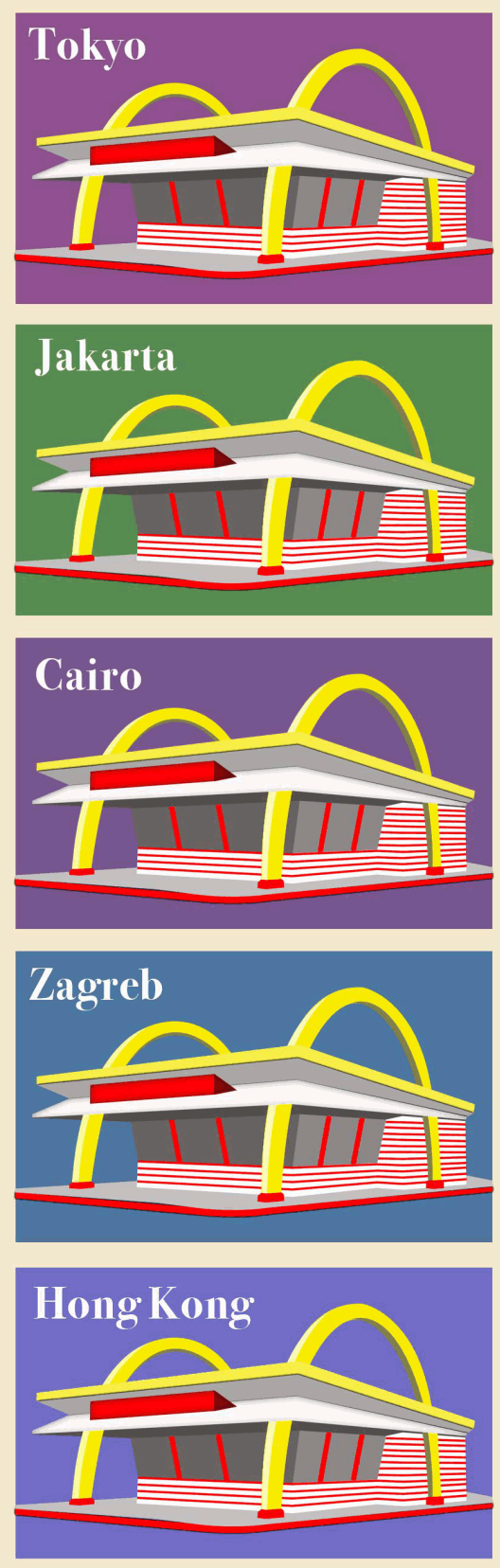

This media review is available in Markets, Globalization \& Development Review: https://digitalcommons.uri.edu/ $\mathrm{mgdr} / \mathrm{vol} 5 / \mathrm{iss} 3 / 5$ 


\section{Film Review}

\section{Elysium as a Social Allegory: At the nexus of Dystopia, Cyberpunk, and Plutocracy}

"The movie is meant to be an allegory for class warfare" - Neill Blomkamp, director (cited in Beckman 2016)

\section{Introduction}

Elysium (2013) is a political dystopian sci-fi action film released in 2013, starring Matt Damon and Jodie Foster, and written and directed by Neill Blomkamp. Although the movie is probably not a science fiction masterpiece and the story integrating social commentary is not idiosyncratic, there is relatively good harmony and symbiosis across the script, action, special effects, music, and the overall cinematography. The subject of this movie being interwoven into the fabric of the overall script remains timely, relevant, and thought-provoking especially concerning what kind of future we are cultivating in this pandemic-impacted world. It also competently manages to incorporate politically astute critique into the blockbuster realm. Overall, this is meant to be a futuristic movie that raises a critique of capitalism with a cyberpunk attitude and aesthetics, and implies that such an unequal political-economic system has impoverished the vast majority of humanity over time and spawned two classes of people: the very few ultra-rich, who live on a massive man-made idyllic floating high-tech space station that orbits the Earth called Elysium and lead a life of luxury, and the rest of the whole world population, who are poor and left behind to struggle to survive on a dilapidated, overpopulated Earth and lead lives full of crime, poverty, and ecological catastrophe.

\section{The Story in a Nutshell and Background}

The protagonist named Max DeCosta (played by the actor Matt Damon) is a decent working-class member of a society who is working hard to put his life in order and make a living for himself and struggling to survive on wages from his job in the factory in an impoverished mega slum called Los Angeles in the year of 2154. In this future, the Earth is devoted only to the poor because the rich and powerful escaped from all the problems such as crime, poverty, and environmental degradation that they may have inherited - 
perhps created? (Boje 2019) - on Earth and fully detached themselves from the struggle of ordinary people by moving to Elysium to continue to live their luxury lifestyles with no interruption. As an orphan child, Max's childhood dream was to earn enough money to buy a ticket to Elysium and take his then-girlfriend Frey (played by the actor Alice Braga) with him. Due to the lack of opportunities in the external environment he had been living in, this childhood dream led him to become a thief in his youth that he thinks may allow him to achieve such a dream. To combobulate his life in his adulthood years, the former criminal Max starts to work at a factory, which is owned and run by a malevolently opulent corporate boss called John Carlyle (a citizen of Elysium, played by the actor William Fichtner), to manufacture an army of androids for the Armadyne corporation designed to control and oppress the masses dwelling on Earth. This factory is one of the very few job opportunities available to the people of Earth and only strong and lucky ones can get the job.

Due to relentless working conditions and the fear of losing his job, Max abides by his supervisor's order and enters into a confined space with no safety precautions and thus exposes himself to a fatal dose of toxic radiation which makes him terminally ill. As a result of such an occupational accident, he is given only five days to live. His only hope is to go to Elysium to take advantage of the high-tech healing machines called Medical Bay so that he can survive. Since this occupational accident has occurred because of the fault of the management in the factory, he initially assumed that he would be given access to Elysium to utilize the healing machines. Yet, things do not progress as planned and the only way left for Max is to fight to gain access to Elysium. With his life hanging in the balance, Max unwillingly takes on a dangerous mission and thus strikes a deal with wouldbe revolutionary underground gangster Spider (Che Guevera of the dark future (see Pletcher 2013), played by the actor Wagner Moura) and agrees to steal data in exchange for a shuttle ride to Elysium. Through the data heist, Spider will be able to reboot the "vulnerable" and broken system to bring equality for all and be able to make everyone on Earth the citizens of Elysium so that they can gain access to the high-tech, state-of-the-art medical care system (Med-Bay) available on Elysium. Spider helps Max acquire a cyborg-like exoskeleton, which gives him augmented strength, agility, reflexes, and endurance as well as a high-tech (yet brutally attached and installed) system through which someone else's brain can be downloaded and the data can be entirely transferred. Hereby, with the help of his best childhood friend Julio (played by the actor Diego Luna) - a friend he trusts the most - and some henchmen whom Spider authorizes, Max hijacks and kills his corporate boss and downloads his brain and translates 
all the data into his brain. The data they steal, however, draws the attention of Elysium's ruthless Secretary of Defense Jessica Delacourt (played by the actor Jodie Foster) and thus she authorizes and designates a henchman called Agent Kruger (played by the actor Sharlto Copley), whose main duty is to kill would-be immigrants trying to reach Elysium, to kill Max and everyone else in his team. At the climax, simultaneously shaping events in the process force Max to sacrifice himself and his life for everyone else to become citizens of Elysium and thus have access to healthcare.

Interestingly enough, the movie seems to have also a religious subtext. Although Max is an anti-hero more interested in saving himself than the world, simultaneously shaping events in the process force Max to sacrifice himself and his life for everyone else to become citizens of Elysium and thus have access to healthcare, which depicts Max as a Christ-figure who strives to stay alive throughout the movie yet, in the end, sacrifices himself to save others and ultimately brings salvation to humankind. Indeed, Yorulmaz (2014) argues Max is more of a Jesus figure than any savior figure for his symbolic mother is a virgin who predicts that Max is the special one destined to change the course of humanity and he is wounded in a fashion similar to that of Jesus and takes the cruciform position when he dies just like Jesus.

\section{Two-World Dichotomy and the Critique of Global Capitalism}

The overarching theme of the movie relies on contemporary but very critical issues concerning social and economic inequality, wealth disparity, poverty, and capitalism/plutocracy. It makes references to the discourses foregrounded and creates space for heated, ardent debate in various public spheres in our everyday lives such as the dilemmas of one percent versus ninety-nine percent, the First World versus the Third World, universal healthcare system, working conditions, anti-immigration laws \& sentiments, open borders, and the like. Broadly speaking, there are two different worlds in the movie, one for the ultra-rich (Elysium) and one for the ultra-poor (the earth). In this notion of ultra-rich and ultra-poor dichotomy that the movie relies on, Elysium represents the First World while the Earth represents the Third World. The citizens of Elysium represent one percent while the people of the earth represent ninety-nine percent. Elysium is a satellite planet in space that orbits the earth and that is visible from Earth for the earthlings to look up to and dream about. This floating luxury planet is designed only for the privileged elite class. One of the key specialties of this satellite planet is that there are magical healing machines (Med-Pads) that not only can cure all sorts of diseases and carry out facial reconstruction and regenerate body 
parts but also bestow favor on the citizens of Elysium with immortality so that they can live forever. On the other hand, the human life on earth is depicted in the movie as a cheap commodity and people of the Earth are not only being vilified but also being murdered insensibly by the Elysium authorities and governmental bodies when they attempt to 'migrate' to Elysium to gain access to such high-tech healthcare devices to cure their serious and fatal ailments. Also, the citizens of Elysium want to preserve their privileged, comfortable, and luxurious way of living and thus do not want the poor people of Earth to migrate to Elysium, therefore the authorities shoot down the shanty shuttles carrying illegal visitors (immigrants) seeking a cure for their ailments or deport them if they could make it through.

The story is very current and relevant because the gap between the have and have-nots has been growing steadily since neoliberal policies have started to dominate the world system and global agenda. The current political system and the powers-that-be show no interest in dealing with such fundamental and central issues and hence manipulate masses via foregrounding the peripheral issues and advertise them as the major challenges that humanity is facing - which may remind us Noam Chomsky's (1998: 43) statement:

The smart way to keep people passive and obedient is to strictly limit the spectrum of acceptable opinion, but allow very lively debate within that spectrum - even encourage the more critical and dissident views. That gives people the sense that there's free thinking going on, while all the time the presuppositions of the system are being reinforced by the limits put on the range of the debate.

Discussing issues concerning social class and class warfare is almost frowned upon in the public sphere while the rich are getting richer and the poor are getting poorer and the middle class is fast shrinking and vanishing. Elysium is a movie ultimately concerned about the social and income inequality between the ultra-rich and everyone else. This movie not only criticizes the idea that only the wealthy can have health care but also present the issues of universal healthcare, open borders such as freedom of migration across borders, and the abolition of class distinctions in a positive light, which may explain why Entertainment Weekly magazine came up with this line: "If you are a member of the 1 percent, Elysium is a horror movie" (see Smith 2013). The movie sheds light on the growing 
polarization of wealth not only in the US but also in the world and highlights the likely consequences that could be spawned when plutocracy combines with oppressive regimes. Elysium is not just a thrilling sci-fi action movie but also an expression of a diligently formulated social allegory for our present conditions. Neill Blomkamp is a director who seems to like to leverage science fiction and action movie genres as instruments to achieve the terminal goal of exploring critical social phenomena and problems from an artistic angle. Similar to his previous critically-acclaimed movie District 9 which concerned itself with the issues of apartheid, immigration, the militaryindustrial complex, and the like - Elysium also concerns with the social issues such as social and economic inequality and exploitation and oppression of the overwhelming majority of people residing on the Earth, which resonates greatly with contemporary societies across the globe. The future of Los Angeles as depicted in the movie looks very much like today's conurbations of the developing world's urban poor. Although this is a futuristic sci-fi movie, to support such a claim, even the director himself states that "this isn't science fiction. This is today. This is now" (cited in Hiscock 2013).

The movie 'Elysium' is redolent of the current coronavirus pandemic crisis in many ways and is yet another dystopian sci-fi movie that insightfully envisioned the future, especially when it comes to the themes related to excess inequality. For instance, the coronavirus outbreak has affected, and continues to affect, the most vulnerable and the least advantaged in contemporary societies. A growing body of research indicates that communities of color - such as Blacks, Latinos, and Native Americans are affected disproportionately by the outbreak across the United States and are "bearing the heaviest burden of COVID-19 at every stage, from risk of exposure, to access to testing, to severity of the illness and eventually death" (Wood 2020). They get sick and die of coronavirus at rates higher than their share of the population and in some states, such rate is around three times their share of the population (Artiga et al. 2020).

Also, the coronavirus crisis is considered one of the greatest economic calamities since the Great Depression and is expected to gradually increase the social and economic inequality and thus widen the gap between rich and poor (Ostry, Loungani and Furceri 2020). Yet, it is apparent that rich and poor people are experiencing the pandemic quite differently. Ultra-rich people may have the means such as private yachts, jets, and islands to escape the pandemic along with their private doctors and test kits and some upper/middle-class people may have the luxury to work from home. On the other hand, front-line/essential personnel - such as delivery workers, garbage collectors, bus drivers, etc. - who have service 
jobs that need to be done in person and who are compelled to take healthrisks and work for their survival are at a greater risk of contracting the coronavirus. That is, working-class neighborhoods are more likely to be affected by COVID-19 than wealthy areas. While the gap between the have and have-nots has been growing fast, Zarroli (2020) suggests that when "the ability to separate yourself from the crowd is literally a life-and-death issue, it's probably not a good moment to show off your yacht".

Most of these deaths from COVID-19 could have been prevented had the employers of at-risk frontline workers implemented appropriate control measures and protective protocols. Yet, unfortunately, corporations and governments that are driven by the neoliberal agenda place profits and business continuity before the health and well-being of their employees and citizens. Some corporations ignore the pandemic and do not even provide their workers with paid sick leave during the coronavirus outbreak (Reich 2020). Additionally, as the scientists are currently working hard to find the most effective vaccines, preventives, and cures to defeat the COVID-19 disease, another challenge will be to ensure equitable access to these similar to access to Med-Bays in the movie - for all countries and population groups across the globe. Yet, it seems like the excess inequality will rear its ugly head once again when it comes to the vaccine because rich nations such as the U.S., Britain, EU, and Japan are first in line and have already secured a lot of doses of potential coronavirus vaccines in advance and thus may monopolize the supply (Paton 2020). It is no surprise that poor nations are concerned about the likely reduction of the global stocks and that they will be left behind in the process of rising vaccine nationalism across the globe (Bailey 2020). Therefore, WHO Director-General states that "when supply is limited, priority must be given to vaccinating essential workers and those most at risk - including older people and those with underlying conditions. In other words, the first priority must be to vaccinate some people in all countries, rather than all people in some countries"(see WHO 2020).

\section{The Symbiotic Interplay of Dystopia and Cyberpunk}

A utopia refers to an imagined society we perceive to be ideal and perfect. Critical theorists and especially postmodernists eschew imagining such a perfect future for our present as it may ultimately lead to the imposition of a grand narrative on all groups as that would reflect only the premise of a modernist project. Dystopia, on the other hand, has been well received by such schools of thought because it primarily functions as a critique of the 
problems of contemporary societies (Felluga 2015) rather than offering a monolithic solution to all problems. In contrast to utopia, dystopia refers to a pessimistic imagined society/world and undesirable, dark, and even noir future version of the present. Echoing Karl Mannheim's arguments in Ideology and Utopia (1998) - that ideology and utopia are intimately connected - we can argue that ideology and dystopia are also strongly intertwined. Dystopias often challenge the neoliberal ideology and capitalism especially due to the system's failure to meet the world population's subsistence needs. According to Mirrlees and Pedersen (2016: 305), Elysium is a critical dystopic movie that formulates "a critique of present-day global capitalism's class divisions and dispossessions, neoliberal security state, ecological catastrophe, and militarized technology." Social antagonism that arises from the real political-economy of our time finds a voice not only in Dystopian music subcultures such as hardcore, punk, metal, etc. (Ulusoy 2016; Ulusoy and Firat 2018) but also in critical dystopian movies (Moylan 2018).

Science-fiction dystopian films have a long history of incorporating wealth disparity and social inequality into their plots as a recurrent social allegory, especially by presenting a stark contrast between the rich and the poor as a consistent metaphor. Some major examples are Soylent Green, Metropolis, Ghost in the Shell (seen review by Mizukoshi 2018 in MGDR), Blade Runner, Equilibrium, Fahrenheit 451, Minority Report, 1984, The Road, and the like. Yet, some people who viewed Elysium may think that we are fast approaching to the future depicted in the movie since capitalism is no longer serving what it used to promise it would serve and nobody in power is doing anything about the rising social and income inequalities after decades of neoliberal governing. Although labeled as dystopian, some may find this movie to be even an optimistic one relative to the perceived future humanity is gravitated towards - which could be even darker than what is portrayed in the movie - especially given "the post-2016 world" is increasingly disturbing, pessimistic and undesirable (Hong 2019).

It is critical to note that Neill Blomkamp's vision of the future seems to have been inspired and influenced by cyberpunk subculture and aesthetics. Broadly speaking, cyberpunk refers to "a subgenre of dystopic science fiction that imagines the future effects of computer technology. A neologism mashing together cybernetics and punk, cyberpunk tends to be set in a dystopic world of social breakdown and often includes plots tied to rebellion by way of hacking (hence the "punk")" (Felluga 2015: 69). That is, cyberpunk is a predominantly dystopian sci-fi subgenre largely associated with technophilia, dark futuristic narratives, nihilism, and hacking culture (Collins 2005). Elysium is a movie that reflects the eclectic constellation of 
the multitude of elements that resonate with the cyberpunk subculture such as dystopia, retro-future technology, androids/robotic cops, megacorporations, income and wealth inequality, a strong message about class struggles, shantytowns, body modification, broken system and social order, and collective grassroots strife to bring equality and justice.

\section{Epilogue: The Dystopian Now}

The ever-crystallizing dichotomy and the massive polarization that exist between the wealthy and poor reflect more of what already exists under capitalism/plutocracy today than any imaginary dystopian future. The fact that we are indeed living in a dystopian world becomes even clearer in times of the pandemic. The coronavirus crisis we are facing today proves that the dystopian sci-fi movie scenarios are not just fantasies or even far-fetched (see the review of 'Contagion' in MGDR, Ozgun 2020). We live in a world today where the top 1 percent have greater wealth than the bottom 90 percent, the 3 richest Americans hold more wealth than the bottom 50 percent of the country, the pay gap between top executives and workers continues to be wide, CEOs make around 300 times the average worker, hundreds of thousands of immigrants are deported each year and families are torn apart, a significant portion of the population cannot afford health insurance or struggle to maintain a low-quality coverage, and last but not least we live in a world where humanity faces serious challenges with the growing environmental degradation, climate change, scarcity of resources, pandemic threats, ceaseless animal massacre, nuclear threat, and booming global population. We need to take a deep breath - assuming we can, given the respiratory ravages of the virus - and ask: "How much more dystopian can things get in a "civil society'?" 


\section{References}

Artiga, Samantha, Bradley Corallo and Olivia Pham (2020), "Racial Disparities in COVID-19: Key Findings from Available Data and Analysis," KFF, August 17, (accessed on September 29, 2020), [available at: https://www.kff.org/racial-equity-and-health-policy/issuebrief/racial-disparities-covid-19-key-findings-available-data-analysis/]

Bailey, Dominic (2020), "Coronavirus: Who would Get the Vaccine First?," BBC, September 11, (accessed on September 23, 2020), [available at: https://www.bbc.com/news/health-54027269]

Beckman, Frida (2016), Culture Control Critique: Allegories of Reading the Present, Rowman \& Littlefield.

Boje, David M. (2019), "Water Avengers and Their Endgame," Markets, Globalization \& Development Review, 4 (4), Article 6, 1-7. https://doi.org/10.23860/MGDR-2019-04-04-06

Chomsky, Noam (1998), The Common Good, Odonian Press.

Collins, Karen (2005), "Dead Channel Surfing: The Commonalities between Cyberpunk Literature and Industrial Music," Popular Music, 24 (2), 165-78. https://doi.org/10.1017/S0261143005000401

Elysium (2013), Director: Neill Blomkamp, Writer: Neill Blomkamp, Distributed by Sony Pictures Releasing, August 9, 2013.

Felluga, Dino Franco (2015), Critical Theory: The Key Concepts, Routledge.

Hiscock, John (2013), "Neill Blomkamp Interview: 'Elysium isn't Science Fiction. It's Now," The Telegraph, August 19, (accessed on July 8, 2020), [available at: https://www.telegraph.co.uk/culture/film/10244979/Neill-Blomkampinterview-Elysium-isnt-science-fiction.-lts-now.html]

Hong, Soonkwan (2019), "Orientalism, Resistance or Global Harmony? Entangled Strands in the Film Isle of Dogs," Markets, Globalization \& Development Review, 3 (4), Article 6, 1-6. https://doi.org/10.23860/MGDR-2018-03-04-06

Mannheim, Karl (1998), Ideology and Utopia, Routledge.

Mirrlees, Tanner and Isabel Pedersen (2016), "Elysium as a Critical Dystopia," International Journal of Media \& Cultural Politics, 12 (3), 305-22. https://doi.org/10.1386/macp.12.3.305 1

Mizukoshi, Kosuke (2018), "Perils of Hollywood Whitewashing?: A Review of 'Ghost in the Shell' Movie," Markets, Globalization \& Development Review, 3 (1), Article 6, 1-10. https://doi.org/10.23860/MGDR-201803-01-06

Moylan, Thomas (2018), Scraps Of The Untainted Sky: Science Fiction, Utopia, Dystopia, Routledge. 
Ostry, Jonathan D., Prakash Loungani and Davide Furceri (2020), "The Pandemic will Leave the Poor further Disadvantaged - IMF," World Economic Forum, May 18, (accessed on September 30, 2020), [available at: https://www.weforum.org/agenda/2020/05/pandemicspoor-rich-economics-coronavirus-covid19/]

Ozgun, Aras (2020), "Steven Soderbergh, Contagion (2011)," Markets, Globalization \& Development Review, 5 (1), Article 5, 1-8. https://doi.org/10.23860/MGDR-2020-05-01-05

Paton, James (2020), "When It Comes to Covid Shots, Rich Nations Are First in Line," Bloomberg, August 2, (accessed on September 30, 2020), [available at: https://www.bloomberg.com/news/articles/202008-02/when-it-comes-to-covid-vaccines-rich-nations-are-first-in-line]

Pletcher, Isaac (2013), "Troubled Angels: Neil Blomkamp's Elysium," Cinema \& New Media Arts, August 10, (accessed on July 8, 2020), [available at: http://cinema.hbu.edu/neil-blomkamps-elysium/]

Reich, Robert (2020), "America's Corporate Elite must Place the Health of Their Workers before Profit," The Guardian, May 17, (accessed on September 23, 2020), [available at: https://www.theguardian.com/commentisfree/2020/may/17/americascorporate-elite-must-stop-treating-coronavirus-as-an-obstacle-toprofit]

Smith, Sean (2013), "Elysium': Future Shock," Entertainment Weekly, July 26, (accessed on July 8, 2020), [available at: https://ew.com/article/2013/07/26/elysium-future-shock/]

Ulusoy, Emre (2016), "Subcultural Escapades via Music Consumption: Identity Transformations and Extraordinary Experiences in Dionysian Music Subcultures," Journal of Business Research, 69 (1), 244-54. https://doi.org/10.1016/j.jbusres.2015.07.037

Ulusoy, Emre, \& Firat, A. Fuat (2018), "Toward a Theory of Subcultural Mosaic: Fragmentation into and within Subcultures," Journal of Consumer Culture, 18 (1), 21-42. https://doi.org/10.1177/1469540516668225

WHO (2020), "WHO Director-General's Opening Remarks at the Media Briefing on COVID-19," World Health Organization, September 4, (accessed on September 30, 2020), [available at: https://www.who.int/dg/speeches/detail/who-director-general-sopening-remarks-at-the-media-briefing-on-covid-19---4-september2020\#: :text=In\%20the\%20coming\%20months\%2C,people\%20in\%2 0some \%20countries] 
Wood, Daniel (2020), "As Pandemic Deaths Add Up, Racial Disparities Persist - And In Some Cases Worsen," NPR, September 23, (accessed on September 30, 2020), [available at: https://www.npr.org/sections/health-shots/2020/09/23/914427907/aspandemic-deaths-add-up-racial-disparities-persist-and-in-somecases-worsen]

Yorulmaz, Bilal (2014), "Elysium," Journal of Religion \& Film, 18 (1), 50, 13. https://digitalcommons.unomaha.edu/jrf/vol18/iss 1/50

Zarroli, Jim (2020), "The Rich Really Are Different. They Can Shelter In Nicer Places," NPR, April 15, (accessed on September 23, 2020), [available at: https://www.npr.org/2020/04/15/834247954/the-richreally-are-different-they-can-shelter-in-nicer-places] 